\title{
FAMILY SUPPORT AND RECURRENCE OF HYPERETENSION IN ELDERLY IN GONDORUSO VILLAGE PASIRIAN LUMAJANG
}

\author{
Eka Suraningtyas \\ STIKES Bhakti Al Qodiri, Jember \\ Corresponding email :
}

\begin{abstract}
BACKGROUND : hypertension is one of common disease in elderly. Family support is require to prevent the recurence of hypertension in elderly. This study is conduct to determine correlationship between family support and the recurence of hypertension in elderly.

SUBJECT AND METHODE : this study is a descriptive correlational study conduct with cross sectional approach involving 40 elderly taken from 198 elderly in Gondoruso Village. The respondents are taken by puposive sampling. The data the analyzed using Spearman Rank statistical analysis with a 0.05 .

RESULT : Spearman rank analysis test show $p$ value of 0.01 less than a 0.05 . Meaning that there is significant correlationship between family support and the recurence of hypertension in elderly.

DISCUSSION : support and encouragement from family is essential for elderly in forming a coping mechanism to overcome stress felt by the elderly. So that family need to involve in treatment of hypertension in eldelry since it play important roles in depress the recurence of disease in elderly.
\end{abstract}

Key words : family support, recurence, hypertension, elderly

\section{INTRODUCTION}

Health and economical problems are common in elderly since the declining of body function naturally and correlate with the fulfillment of dailiy needs. It does not mean that the problems in other sector is not important. Other sectors such as demographical structure, education, social activity, and violence in elderly are also need comprehensive attention (Elderly National Comission, 2012).

Elderly as an end life cycle is a normal stage of development and no one could avoid it (Stanley, 2007). The number of elderly are predict more than 629 million worldwide and projected to be 1.2 billions of people at 2025 (Nugroho, 2012). Indonesia is one of country which has high number of elderly people. Statistical Center of Indonesia projected that between 2005- 2010 the number of elderly is about 19 million or $8.5 \%$ from the total number of citizens. WHO is also predict that Indonesia will face the largets increasing of elderly in worldwide at 2025 , which is counted as $41.4 \%$ (Maryam, 2012).

WHO and the Law Number 13 of 1998 about elderly's wellfare in article 1 paragraph 2 stated that 60 years old is the beginning of old age. Aging is not a disease, but it is a process that gradually results in cumulative changes. Aging is a declining body function process from inside to outside of the body and ended with death (Padila, 2013).

The number of pre elderly and elderly in Regency of Lumajang during 2012 who get health services is counted 60,663 from total of 118,366 elderly or $51.25 \%$. (Health Office of Lumajang, 2012). Many efforts has been taken by the health office of Lumajang to improve elderly's quality of life. Those are by conduct a posyandu which is included elderly excercise that could lower the anxiety level and effective in decreased hypertension in elderly. Another effort is by conduct a health promotion especially to organize and providing 
care to the elderly. According to the study conducted by Chandra (2006) stated that there is a significant differences between level of anxiety of male and female elderly. The female elderly tend to have severe anxiety to all aspect of her life compared to male elderly.

Hypertension is a common disease in elderly. This condition wa characterized systolic pressure is abve $140 \mathrm{mmHg}$ an the diastolic is less than or in point of $90 \mathrm{mmHg}$ that could lead to emerge of continued sign and symptoms such as stroke and coronary heart disease (Keliicker, 2010).

Elderly with hypertensoin tend to have difficulties in doing self care management to themselves and it could worst their condition. Healthy people 2010 for hypertension recommended the use of an comprehensive and intensive approcach to achieve controlled blood pressure. One factor that affect self care management is family (Flynn et al, 2013; Ho TM, Maryam et al, Stanhope and Lancaster). Family support is the application of four characteristics of family social support, such as informational support like giving advice, direction,and required idea; emotional support like symphaty, emphaty, love, trust, and respect; intrumental support including cost. Transportation, medication, and asessment for example family giving praise for what have been done by the patients (Setiadi in Indah, 2012).

Most people with hypertension are feeling healthy. Sign and symptoms like headache are consider not a problem. They believe that taking medicine could help them feel better. Family support is an imprtant thing that has to be done to prevent hypertension in elderly especially hypertension controlling in elderly. Those statement is the background for the author to takes the title Family Support and Recurence of Hypertension in Elderly in Gondoruso Village, Pasirian, Lumajang. This study is conducted to determine the correlationship between family support and the recurence of hypertension in elderly.

\section{METHODE}

Research design adjusts to the research goals and problems. Observational can be descriptive corelative. The research design uses a correlative descriptive method to describe two interrelated variables, namely the correlationship of family support and recurence of hypertension in Gondoruso Village, Pasirian, Lumajang.

The research design is a concept or model that describes how the research is carried out to achieve the research objectives. There are various kind of research design, and this study using cross sctional approach becaause the researcher take measurements or observations at the same tome(once in a while, 2012).

Population in this study are some elderly aged 45 years in Gondoruso Village. The population counted as 198 elderly. While sample is a part of population studoed. The respondents was the edlderly who fufilled the middle aged requirements (45-59 years old) in Gandoruso village. The respondents was taking by purposive sampling.

To apply a statsistical test it must be adjusted to the measurement scale, type of measurement and type research conducted. The statitical test apply in this study is Speraman Rank analysis to determine the correlationaship between family support and recurence of hypertension in elderly. 


\section{RESULTS AND DISCUSSION}

\section{Family Support}

After the observation, it was found that respondents with good family support 12 respondents (30\%) does not experience the recurence of hypertension. While respondents with lack of family support, 8 respondents (20\%) is often experience hypertension recurence. And 20 respondents who got sufficient family support seldom experience the recurence of hypertension.

Nawawi (2010) stated that there were some factors affected elderly's mental health which is declining physical function, declining sexual function, psychological changes, and shifting role in community and changes in occupation. If those factors does not responded wisely, it will bring some problem in elderly's mental health.

Mental unpreparedness in facing retirement, make individuals become anxious, stressed and depressed. This phenomenon clearly brings a number of consequences that will cause psychological problems in the elderly, namley stress (Hutapea, 2012). Individual who experienceing stress can be seen from the changes that occur in his physical condition. Sign ans symtopms of stress including angry, moody, anxious, sad, depressed, pessimistic, crying, shifting mood, declining self esteem or feel insecured, succumbed easily and has hostile attitudes, nightmare and experience impaired concentration and memory (Hawari, 2010).

Support system is required to deal with stress and this support could come from family. When experienceing a problem, someone will seek upport from people around to help and reawaken the spirit and confidence in facing the difficulties. So that, individuals feel valued, cared for, loved and do not feel alone in facing a problem (Koentjoro, 2012).

\section{Recurence of hypertension}

From the total of 40 respondents, majority of respondents are seldom experiencing the recurence of hypertension which is counted 20 respondents $(50 \%)$.

According to The Health belief model theory the effort that has been done by the respondents in Gondoruso village is chategozied as good.

Any effort to prevent the recurence is done according to the individual perception about the threat, seriousity, history of disease and consideration of advanteges and disadvantages. Individual perception is affected by modificational factors including demographic variables (age, gender, and culture background), sosiological factors (personality, social classes, and social stressed), and structural variables (knowledge and previous experience) (Heri, 2009). Modificational factor in this study including age, gender and knowledge about the disease.

Health belief model stated by Rosenstock (2012) is one of cognitive model that can be use to determine health behavior. Health belief model provides a framework for understanding spesific measure as preventive neasure (Sumijatun, 2006 in Kumoboyono, 2011). In health belief model, preventive behavior is determined by individual believe that he is vulnerable to health problems, consider the health problem is serious, believe in effectivity of prevention and medication, affordable and accepting advice to take action (Rochadi, 2013).

Effort to prevent recurrence in term of perceived vulnerability are also based on the ability of individuals to feel how likely it is that they will recure if prevention is not done. So that if the individual does not feel that what he is suffering is a risk and becomes a threat and becomes a threat to him then that individual will not seek treatment and take precautions. 
Age and sex factors also affect vulnerability. Where the elderly age group and female sex have a higher susceptibility to recurence of hypertension. According to Hegner (2013) body changes due to the aging procces make the eldelry vulnerable to disease. Old age has a less immune system against disease because of a low immune system in line with increasing age.

Aspect of gender, women are more vulnerable than men where the highest percentage of people with hypertension are women. This is consistent with the research conducted by Khoman (2010). Harrison (2000) stated that extraordinary human race also affect the disease and also the incidence and clinical sign of the disease.

\section{Correlationship between family support and recurrence of hypertension}

Analytical statistic show $p$ value of 0.01 smaller than 0.05 mean that there is a significant correlationship between family support and the recurrence of hypertension.

According to Walker et al (2005) humans are one of the socail creatures that live in families in which they are interconected with one another. When dealing with problems in general, sharing and giving assistance. This was done as a form of support.

Family refers to two or more people who are united by by the ties of togetherness and emotional ties and who identify themselves as part of familiy (Friedman, 1998). It is generally accepted that people who live in a supportive environment are far better off than those who do not have them. More spesifically family support can weaken the impact of stress and can directly strengthen the mental health of individuals and families (Friedman 1998).

Rasmun (2004) stated that a family support system that is given to both listening, giving advice and encouraging emotions is very useful for someone who is in a state of hypertension. In general, people who live in a supportive environment, conditions are much better than those who do not have ut. Support is considered to weaken the impact of stress in the study mentioned that support is a buffer and sirectly strengthen the mental health of individuals and families. Support is said to be an important coping strategy for families to deal with stress. Support can also functioning as a preventive strategy to reduce stress and its negative consequences (Friedman, 1998)

\section{CONCLUSION AND RECOMMENDATION}

Family support is an interpersonal relationships that provide assistance to individuals in the form of attention, emotions, instrumental assistance, providing information and asessment to individual in their social environment. The result of this study show that respondents with good family support 12 respondents $(30 \%)$ does not experience the recurence of hypertension. While respondents with lack of family support, 8 respondents $(20 \%)$ is often experience hypertension recurence. And 20 respondents who got sufficient family support seldom experience the recurence of hypertension.

Effort to prevent relapse in terms of the ability of individuals to feel how likely they will suffer a recurrence if prevention is not done. So that if the individual does not feel what he is suffering, it is a risk and become a threat to him. He will not seek treatment and take precautions. From the total of 40 respondents, majority of respondents are seldom experiencing the recurence of hypertension which is counted 20 respondents $(50 \%)$.

Analytical statistic show $p$ value of 0.01 smaller than 0.05 mean that there is a significant correlationship between family support and the recurrence of hypertension. 
From all the conclution above, we recommend that :

1. Health care provider should aware that support, motivation and attention from family could be a therapy to minimize the risk of hypertension recurence in elderly. An approcah based on family could be one of treatment to supress the incidence of hypertension in the family.

2. Family should be aware and sensitive in monitoring family member who has hypertension, to be able to find out early treatment in case of recurrence.

\section{REFERENCE}

Akhmadi, 2014. Hubungan Dukungan Keluarga dengan Kualitas Hidup Penderita Hipertensi di Puskesmas Lamongan.

Arikunto, S. 2006. Prosedur Penelitian, Suatu Pendekatan dan Praktek. Jakarta: PT. Rineka Cipta.

Azizah, L.M. 2011. Keperawatan Lanjut Usia. Yogyakarta: Graha llmu.

Bandiyah, S. 2009. Lanjut Usia Dan Keperawatan Gerontik. Yogyakarta: Numed

Bangun, 2012. Peran Keluarga dalam Perawatan Penderita Hipertensi Secara Mandiri di Rumah. Karya Tulis IImiah strata satu, Universitas Muhammadiyah Yogyakarta, Yogyakarta

Beavers, G.D. 2008. Bimbingan Dokter Pada Tekanan Darah. Jakarta: Dian Rakyat.

Bomar, P.J. 2004. Promoting Health In Families: Applying Family Research And Theory To Nursing Practice. Philadelphia: W.B. Saunders Company

Candra, 2014. Kualitas Hidup Lansia di Kecamatan Sumbersari Kabupaten Jember.

Darmojo, B. 2006. Buku Ajar Boedhi-Darmojo: Geriatri (IImu Kesehatan Usia Lanjut). Jakarta: FKUI.

Demartoto, 2012. Hubungan Dukungan Keluarga dan Beban Keluarga dalam Merawat Anggota dengan Riwayat Perilaku Kekerasan di RS Jiwa Klender Jakarta Timur. Diakses pada 18 Januari 2017

Dewi, 2012. Hubungan Dukungan Keluarga dengan Lansia Penderita Hipertensi. Diakses pada 18 Januari 2017.

Dinas Kesehatan Kabupaten Lumajang. 2014. Profil Kesehatan Kabupaten Lumajang 2014.

Dinas Kesehatan Provinsi Jawa Timur. 2015. Profil Kesehatan Jawa Timur 2015 Pemerintah Jawa Timur Dinas Kesehatan.

Domas Fitria, dkk. 2012. Peningkatan Pengetahuan Tentang Hipertensi Pada Lansia Di Posyandu Lansia Dukuh Gantungan Desa Makamhaji Kartasura Sukoharjo. E-Journal Mahasiswa Fakultas Kedokteran Universitas Muhammadiyah Surakarta.

Effendi, 2012. Hubungan Kadar Darah Tidak Terkontrol dan Lama Menderita Hipertensi, dengan Fungsi Kognitif pada Subyek Hipertensi. Jurnal e-clinic

Flynn et al., 2013. Health promotion by social cognitive means. Health Education \& Behavior. Family support for hypertensive elderly.

Friedman, M. M., Bowden, V. R., \& Jones, E. G. 2010. Buku Ajar Keperawatan Keluarga: Riset, Teori \& Praktik. Alih bahasa oleh Achir Yani S, et al.

Handayani Dwi, 2012. Analisis Kualitas Hidup Pasien Hipertensi di RSUD Bangil Kabupaten Pasuruan. Diakses 18 Januari 2017

Hendriyana, 2012. Penatalaksanaan Hipertensi dengan Pendekatan Keluarga. Dalam S. Soegondo, P. Soewondo.

Herliah Lily, 2013. Hubungan faktor umur, jenis kelamin, kegemukan dan hipertensi dengan kejadian DM tipe 2 di wilayah kerja Puskesmas Mataram. Diakses pada 8 Januari 2017, dari http://www.lpsdimataram.com/phocadownload.pdf

Hu, H., Li, G., \& Arao, T. 2013. Prevalence rates of self-care behaviors and related factors in a rural hypertension population:a questionnaire survey. International Journal of hypertension.

Hutapea, 2013. Hubungan Dukungan Sosial Keluarga dengan Kualitas Hidup Pasien Hipertensi. Diakses pada 18 Januari 2017. 
Indah. 2012. Analisis Faktor-Faktor yang Mempengaruhi Keluarga untuk Memberikan Dukungan Kepada Klien Diabetes Melitus dalam Menjalani Diet. JOM PSIK.

Khulaifah Siti dkk, 2013. Analisis Faktor-Faktor yang Mempengaruhi Keluarga untuk Memberikan Dukungan Kepada Klien Hipertensi dalam Menjalani Diet.

Lalu Febrian P.P. 2012. Hubungan Pengetahuan Tentang Hipertensi Dengan Perilaku Pencegahan Primer Di Desa Nyatnyono Kecamatan Ungaran Barat. E-Journal Mahasiswa Program Studi Kesehatan Masyarakat STIKES Ngudi Waluyo Ungaran. 